\title{
A Systematic Literature Reviewe of Performance Management of Zakat Funds Institutions on Redistribution of Indonesian Revenue
}

\author{
Zainiyatul Afifah \\ Department of Management, STIE Perbanas Surabaya, Surabaya \\ e-mail:2018611003@students.perbanas.ac.id
}

\begin{abstract}
The main purpose of zakat as an Islamic financial instrument that aims as an equal distribution of revenue and maslahah. Indonesia with the Muslimmajority community, has great potential in collecting zakat funds, it is expected to be a solution to the income inequality and poverty in Indonesia. However, the realization of zakat still far from the potential. It is indicate that the performance of zakat fund management institutions has not been maximized.This study aims toreview and organize the performance management of zakat fund institution and organize its impact on income equality and poverty in Indonesia. This study provides a qualitative and critical review of efficiency performance management zakat fund institution and theinfluence on income distribution and poverty alleviation in IndonesiaBy critical review and classifying the result of previous research found some propositions: (1)Management of zakat funds have affect on the performance of zakat institutions (2) the efficiency of the performance management of zakat fund institutions have impact on the equitable distribution of zakat funds (2) the effectiveness distribution of zakat fund institution have a significant affect on poverty alleviation and equitable distribution of income.
\end{abstract}

Keywords - Zakat Fund Institution, Performance Management, Income Equation, Poverty Alleviation, Efficiency, Literature Review.

\section{INTRODUCTION}

$\mathrm{Z}$ AKAT is one of the Islamic financial instruments that has been developed and developed since the time of the Apostle, even in the days of friends and Khulafur Rasyidin zakat management is optimized as a source of financial finance and national development sources of financing warfare in the expansion of the area of the spread of Islamic religion. In Islamic perspective, a promising institution that can be utilized to reduce poverty and achieve social welfare is Zakah institution.

Zakah, one of the five pillars of Islam, is a share of the poor on the wealth of the rich.he obligation of zakah is clearly mentioned in the Qur'an, where it is specifically targeted to eight groups ofpeople namely the poor (fuqara), needy (masakin), administrator of zakah funds (amil), converts (muallaf), those in bondage (riqab), those indebted (gharimin), those in the cause of God (fi sabilillah) and the wayfarer in need (ibnusabiil). Viewed this way, from a

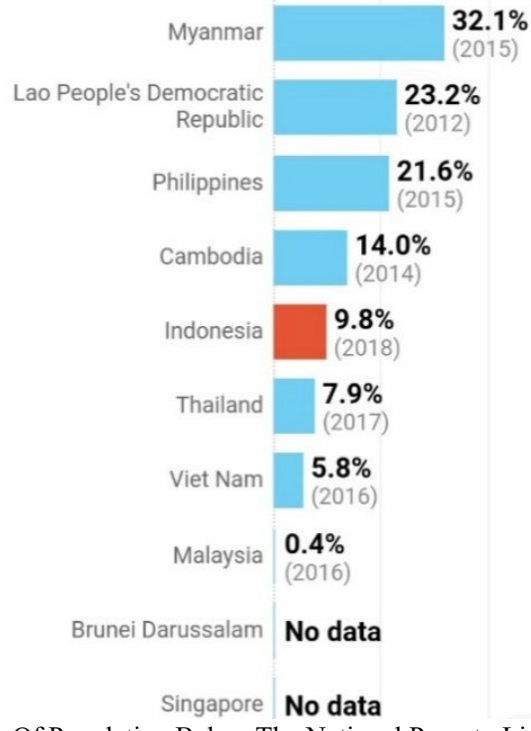

Figure 1. Share Of Population Below The National Poverty Line (\%)

development perspective, zakah could also be considered as a specific targeting instrument aimed to reduce poverty [1].

The proper use of zakat is believed to be able to increase socio-economic justice and fair distribution of income. Because when someone pays zakat, the rate of economic growth will be higher.In other words, zakat as the financial system will integrate to bridge this gap and the reduction of social problems in Muslims world as well as may contribute in economic activities in order to achieve sustainable development. With the result that zakat can be used as one of the right indicators to measure economic growth.

Zakat could be employed as an essential tool to stimulate human development. The distribution of zakat for education and human resources empowerment is stimulated better social life of the recipients. Thus the increase of zakat in the short run can increase the social life, quality of education and quality of recipients. In the long run can increase consumption, investment, demand for labor, and stimulate zakat recipient became zakat payers. The increasing social life which can be defined as an expectancy and education are part of indicators which use to measure the Human Development Index (HDI) [2].

Poverty and social inequality are problems that are almost faced by all developing countries, including Indonesia, the 
The $1^{\text {st }}$ International Conference on Business and Engineering Management (IConBEM)

February $1^{\text {st }} 2020$, Institut Teknologi Sepuluh Nopember, Surabaya, Indonesia

Table 1.

The Accepted Related Articles

\begin{tabular}{|c|c|c|c|}
\hline No. & Title & Author/S & Year \\
\hline 1 & Analysis Of Financial Performance Of National Amil Zakat Institutions In Indonesia & Ani QotuzZuhro, Dkk & 2019 \\
\hline 2 & The Multiplier Effects of Zakat & Binish Qadri & 2019 \\
\hline 3 & The Effectiveness Of Zakat In Developing Muslims In Malaysia & Khairul Azhar Meerangani & 2019 \\
\hline 4 & The Efficiency Of Zakat Institutions In Indonesia In 2012-2016 & Suhail, Dkk & 2019 \\
\hline 5 & $\begin{array}{l}\text { Zakat Untuk Mengurangi Angka Ketergantungan Ekonomi Dengan Penyaluran Model } \\
\text { Usaha Produktif }\end{array}$ & Mochlasin & 2018 \\
\hline 6 & Efektivitas Tata Kelola Dana Zakat & Dewi Susilowati Dan Chrisyina Tri Setyoni & 2018 \\
\hline 7 & $\begin{array}{l}\text { Examining The Efficiency Of Zakat Management: Indonesian Zakat Institutions } \\
\text { Experiences }\end{array}$ & Solahuddin Al-Ayyubi & 2018 \\
\hline 8 & Zakat For Proverty Alleviation And Income Inequality Reduction: West Java Indonesia & QurrohAyuniyyah & 2018 \\
\hline 9 & $\begin{array}{l}\text { Analisis Zakat Produktif Terhadap Indeks Kemiskinan, Nilai Material Dan Spritual Para } \\
\text { Mustahik }\end{array}$ & Nono Hartono & 2018 \\
\hline 10 & Optimization Of Zakat Fund Management In Regional Zakat Institution & Tikawidiastuti & 2018 \\
\hline 11 & Measuring The National Zakat Index (NZI) On Zakat Performance In Bogor Regency & Ulfah Laelatul Hilmiyah, Dkk & 2018 \\
\hline 12 & Tingkat Efisiensi Dan Produktivitas Lembaga Zakat Di Indonesia & Salman Al Parisi & 2017 \\
\hline 13 & Zakat Dalam Mendorong Pertumbuhan Ekonomidan Pengentasan Kemiskinan & Abdul Haris Romdhoni & 2017 \\
\hline 14 & Zakat Investment in sharia & N. Gafordeen & 2016 \\
\hline 15 & The Efficiency Of Zakah Institutions Using Data Envelopment Analysis & $\begin{array}{l}\text { Aam Slamet Rusydiana Dan Salman Al- } \\
\text { Farisi }\end{array}$ & 2016 \\
\hline 16 & Effectiveness Of Zakah Targeting In Alleviating Poverty In Indonesia & Kasri & 2016 \\
\hline 17 & Measuring Zakat Impact On Poverty And Welfare Using Cibest Model & Irfan Syauqi Beik Dan Laily Dwi Arsyianti & 2016 \\
\hline 18 & $\begin{array}{l}\text { Kinerja Lembaga Zakat Dalam Pemberdayaan Ummat (Studi Pada Web Dompet Dhuafa, } \\
\text { Lazis Nu Dan Lazis Muhammadiyah) }\end{array}$ & $\begin{array}{l}\text { Muhammad Munadi Dan Muslimah } \\
\text { Susilayati }\end{array}$ & 2016 \\
\hline 19 & $\begin{array}{l}\text { Pengukuran Efisiensi Organisasi pengelola Zakat Dengan Metode Data Envelopment } \\
\text { analysis }\end{array}$ & Aulia Zahra & 2016 \\
\hline 20 & $\begin{array}{l}\text { Preferensi Masyarakat Terhadap Lembaga Zakat Dan Bentuk-Bentuk Pemberdayaan } \\
\text { Dana Zakat }\end{array}$ & Ahmad Mifdlol Muthohar & 2016 \\
\hline 21 & $\begin{array}{l}\text { Analisis Efesiensi Lembaga Amil Zakat Terhadap Pengentasan Kemiskinan (Studi Kasus } \\
\text { Di Laz Usp 2008-2013) }\end{array}$ & $\begin{array}{l}\text { Muhammad Khafidh Abdillah BilHaq Dan } \\
\text { Royyan Ramdhani Djayusman }\end{array}$ & 2015 \\
\hline 22 & $\begin{array}{l}\text { Efisiensi Kinerja Keuangan Badan Amil Zakat Daerah (Bazda): Pendekatan Data } \\
\text { Envelopment Analysis (Dea) }\end{array}$ & Alfi Lestari & 2015 \\
\hline 23 & Manajemen Pengelolaan Zakat yang Efektif Di Era Kontemporer & Ahmad Atabik & 2015 \\
\hline 24 & Pengentasan Kemiskinan Melalui Pemberdayaan Zakat & Nur Ahmad & 2015 \\
\hline 25 & Pengumpulan Dan Pendayagunaan Zakat Infak Dan Sedekah & Fifi Nofiaturrahmah & 2015 \\
\hline 26 & $\begin{array}{l}\text { Peran Zakat Dalam penanggulangan Kemiskinan (Studi Kasus: Program Zakat Produktif } \\
\text { Pada Badan Amil Zakat Nasional) }\end{array}$ & Yoghi Citra Pratama & 2015 \\
\hline 27 & Peranan Zakat Dalam Pengentasan Kemiskinan & Ahmad Atabik & 2015 \\
\hline 28 & Zakat Ibadah Sosial Untuk Meningkatkan Ketaqwaan Dan Kesejahteraan Sosial & Ahmad Syafiq & 2015 \\
\hline
\end{tabular}

number of poor people in Indonesia according to the Central Statistics Agency (BPS) per year 2019 of 9.41 percent, decreased 0.25 percent against September 2018 and decreased 0.41 percent against March 2018. The number of poor people in March 2019 was 25.14 million people, decreasing 0.53 million people in September 2018 and decreasing 0.80 million people in March 2018.

However, although poverty in Indonesia has decreased, the World Bank in its latest report said, as many as 6 proventions in Indonesia actually experienced an increase in poverty, especially in Eastern Indonesia with the highest Papua provention of 27.5 percent.This shows that there is a high degree of inequality, considering that Jakarta has the lowest poverty rate of 3.5 percent.

In addition, if we look further at the position of Indonesia, it is ranked fifth among the poor countries among other ASEAN countries, namely, after the Philippines and Cambodia.
Poverty and social inequalities can be minimized, one of which is by using the Zakat instrument as a mediator between people who earn more income from people who are economic constraints.

In alleviating the problem of poverty, Islam promotes a solution that is very precise and effective, that is making it compulsory for qualified Muslims to give alms or zakat [3].

thus, this present study intends to look deeper into the efficiency manajaman zakat institution in eradicating poverty of Indonesia. The main purpose of zakat is to help the poor and needy by distributing zakat collected to these two groups (poor and needy) and this means zakat has the potentials to contribute to poverty eradication and inequality distribution.

In addition, Indonesia as a dense country with a majority Muslim population, even including a country with the largest Muslim population in the world, certainly has a large zakat potential. And in 2018, based on data from the National Amil Zakat Agency (BAZNAS) that in 2019 the potential for 
The $1^{\text {st }}$ International Conference on Business and Engineering Management (IConBEM)

February $1^{\text {st }} 2020$, Institut Teknologi Sepuluh Nopember, Surabaya, Indonesia

Table 2.

The Rejected Related Articles

\begin{tabular}{|c|c|c|c|}
\hline No. & Title & Author/S & Year \\
\hline 1 & $\begin{array}{l}\text { Empowering Wakaf And Zakat In The Provision Of Affordable Housing } \\
\text { Through Collaborative Procurement }\end{array}$ & Khairuddin Abdul Rashid, Dkk. & 2019 \\
\hline 2 & Komparasi Kinerja Keuangan Lembaga Amil Zakat & Prayogo P. Harto & 2018 \\
\hline 3 & $\begin{array}{l}\text { Membangun Good Governance Di Lembaga Amil Zakat, Infaq Dan Sadaqah } \\
\text { (Laz): Pengalaman Dua Laz Besar Di Indonesia }\end{array}$ & Ahim Abdurahim & 2018 \\
\hline 4 & $\begin{array}{l}\text { The Direct and Indirect Effect of Zakat on the Household Consumption of } \\
\text { Mustahik (A Study ofZakat Recipients from BAZNAS Probolinggo } \\
\text { Municipality) }\end{array}$ & Elok Nurlita and Marlina Ekawaty & 2018 \\
\hline 5 & A Framework To Analyse The Efficiency And Governanceof Zakat Institutions & $\begin{array}{l}\text { Norazlina Abd. Wahab Dan Abdul Rahim Abdul } \\
\text { Rahman }\end{array}$ & 2016 \\
\hline 6 & $\begin{array}{l}\text { Construction Of A Performance Assessment Model For Zakat Management } \\
\text { Institutions }\end{array}$ & Sri Fadilah & 2016 \\
\hline 7 & The Discourse of Zakat Management Based on the Natures of States & Cucu Solihah & 2015 \\
\hline 8 & Prospek Zakat Dalam Perekonomian Modern & Ahmad Syafiq & 2014 \\
\hline 9 & $\begin{array}{l}\text { The Efficiency of Zakat Collection and Distribution: Evidence from Two Stage } \\
\text { Analysis Ismail HJ }\end{array}$ & Ahmadand Masturah Ma'in & 2014 \\
\hline 10 & $\begin{array}{l}\text { Urgensi Manajemen Zakat Dan Wakaf Bagi Peningkatan Kesejahteraan } \\
\text { Masyarakat }\end{array}$ & Qurratul Aini Wara Hastuti & 2014 \\
\hline 11 & $\begin{array}{l}\text { Determinants Of Efficiency Of Zakat Institutions In Malaysia: A Non- } \\
\text { Parametric Approach }\end{array}$ & $\begin{array}{l}\text { Norazlina Abd. Wahab Dan Abdul Rahim Abdul } \\
\text { Rahman }\end{array}$ & 2013 \\
\hline 12 & Role Of Zakat To Eradicate Poverty In Malaysia & MohdRodziEmbong, Dkk. & 2013 \\
\hline 13 & $\begin{array}{l}\text { Tingkat Keberhasilan Program Pendayagunaan Zakat Produktif pada Baitul } \\
\text { Mal Provinsi Aceh }\end{array}$ & Nurlaila Dan Nevi Hasnita & 2013 \\
\hline 14 & $\begin{array}{l}\text { Efficiencyof Zakat Institutions In Malaysia: An Application Of Data } \\
\text { Envelopment Analysis }\end{array}$ & $\begin{array}{l}\text { Norazlina Abd. Wahaband Abdul Rahim Abdul } \\
\text { Rahman }\end{array}$ & 2012 \\
\hline 15 & $\begin{array}{l}\text { Zakat Impact on Poverty and Welfare of Mustahik: A CIBEST Model } \\
\text { Approach }\end{array}$ & Irfan Syauqi Beikand Caesar Pratama & - \\
\hline
\end{tabular}

receipt of zakat in Indonesia has reached Rp233,8triliun. But in reality this potential has not yet been realized [4].

The low realization of zakat on its potential as well as the great opportunity of zakat in overcoming poverty and the equal distribution of income and welfare in Indonesia, is a reason for researchers to analyze the extent to which management efficiency of existing zakat funds and their relevance in overcoming poverty existed through critical review of previous research.

thus, the contributions of this study can be qualifiedfrom review of the trends, opportunities and challenges ofconstitutes an aid for other investigationsthat intend to study these in greater depth

\section{METHOD}

In this paper, a systematic literature review wasused, which, having its origins in thefield of management zakat institution, has subsequently seen the adoption of its characteristicsin the social sciences [5].

Systematic LiteratureReviewis a term used to refer to a research methodology or specific research development carried out to collect and evaluate research related to the focus of a particular topic [6].

SLR research is carried out for a variety of purposes, including to identify, study, evaluate, and interpret all available research in the subject area of an interesting phenomenon, with certain relevant research questions [7], [8]. SLR is also often needed to determine the research agenda, as part of a dissertation or thesis, and is a part that complements the submission of research grants

The process for this research is based on the five steps proposed by Khan et al. for the research based on systematic review, in which the authors provided an explanation of the tasks accompanying a systematic literature review such as selecting, reviewing and quality assessment of the reviewed literatures [9]. The five steps are and the actions taken by the researchers are follows:

1-Framing the question for the review. In this step, the research question and the related terms should be clearly specified before the start the of the actual literature review. In the case of this research, there are two parts or two research questions:

QR1:Is the Performance Management of Zakat funds Institution is effective?

QR2: Is Effectivisness of Zakat funds Institution can can be a financial instrument for poverty alleviation and income inequality

QR3: What factors will be an improvement in maximizing the effectiveness and capacity of Zakat fund management institutions for equitable distribution of national income?

2-Identifying relevant work and literatures. To capture as many relevant citations as possible. For this study, the focus is on the electronic resources and documents that contain the following keywords: 'the effectiveness of zakat', 'equitable distribution of income'and 'zakat in poverty alleviation. More specifically, the resources were journals that are 
The $1^{\text {st }}$ International Conference on Business and Engineering Management (IConBEM)

February $1^{\text {st }} 2020$, Institut Teknologi Sepuluh Nopember, Surabaya, Indonesia

Table 3.

Previous Studies That Obtained Effective Results

\begin{tabular}{clc}
\hline \hline No. & \multicolumn{1}{c}{ Daerah } & Tahun \\
\hline 1 & Lombok & $2012-2014$ \\
2 & West Java & $2015-2016$ \\
3 & Nasional (15 IZI) & $2010-2016$ \\
4 & Nasional (BAZNAS \& LAZNAS) & $2014-2016$ \\
5 & LAZISNU & 2015 \\
6 & Bogor & 2015 \\
7 & Acel & 2013 \\
8 & Boyolali & 2016 \\
9 & Jawa Barat & 2016 \\
\hline \hline
\end{tabular}

concerned with Zakat, inequality distribution such as (Emerld, Iqtisaduna, Journal of Economic Islami)

3-Assessing the quality of the found studies. In this step, the discovered papers or publications would be filtered according to some quality measures to filter the found publications. These standards are:

The paper must clearly relate to the research question

The publication must have clear methodology

The research must come from trusted resources and journals. In this regard, papers that are based on a single case study were excluded, since the findings cannot be generalized

The publication year of the papers must be 2014 or above

4-Summarizing the evidences that answer the research question. In this step, the discovered evidences related to the research questions will be gathered and summarised in order to prepare them for fifth step which is data analysis or findings interpretations.

5- Interprating the findings. In this final step of the study, the discovered results from the previous steps would be analysed in order to conclude the stakeholders groups in the ERP implementation project as well as CSFs that concern each of these groups.

Critical Success Factors can be defined as the aspects or elements that need to be considered carefully in order to have a successful project. This definition can be applied to the Zakat for equitable distribution and poverty allevition projects.

Based on this explanation and on the importance of examining the Critical Success Factors in ERP Implementation, 46 articles have been investigated thoroughly in order to determine their relevance to the topic under investigation and also to answer the research questions for this study. Table 1 lists the 28 articles that have been key word, effectiveness zakat, poverty allevition and equitable zakat and Table 2 lists the 15 papers that were examined and rejected. These articles were rejected because one or more of the following reasons:

1. The year of publication is older than 2015

2. Some articles were based on single case studies-Some papers were not related directly to the Zakat for equitable distribution and poverty allevition

3. Some papers were based on previously published conference proceedings and then updated and published in an international journal.
4. The keywords that were used to filter the papers in this part of the study are:" effectiveness of zakat', 'zakat in equitable distribution of income'and 'zakat in poverty alleviation.

\section{Effectivisness of Zakat in Islam}

The effectiveness of zakat is referring to inputs and outputs in management activities to determine how inputs turn into outputs with predetermined conditions [10].

So it can be concluded that the management of zakat can be said to be effective zika between the existing input and output can be optimized or in other words the output does not exceed the input, or each output expenditure can get a balanced input.

The concept of efficiencyin Islam by presenting a previous study. and explain the input and output approaches of conducting economic activities in accordance with Islamic teachings. One input is based on aqidah (amantubillahithummastaqim), the principle of having ability (khairunnasianfauhumlinnasi), and to be grateful for achievement (man lam yashkurinnasa lam yashukurillaha), and not wasteful (israf) and squandering (israf) and squandering nyakan (tabr) with output.

The author explains the concept of optimizing input and output in accordance with the Qur'an and Hadith.

1. Optimizing Input Alharitsi (2003: 64) states that Muslim producers place a great trust in God with regard to business results and profits, because everything is predetermined. Ali and Ascarya (2009: 114) describe three main factors needed to optimize production inputs, as described below:

a. Utilizing Natural Resources The Qur'an explains the role of a Muslim as the caliph's earth. With this trusteeship, a Muslim must be careful in using natural resources to meet the needs of the people. "And to the Thamud [We sent] their brother, Salih. He said," O my people, worship Allah; You have no god but Him. He has produced you from the earth and placed you in it, so ask for forgiveness from Him and then repent to Him. Really, my Lord is close and responsive. "' (Huud: 61).

b. Equal Paymentsand Fair. Hadith Rasulullah SAW emphasized that workers have the right to relevant workers' rights. Abdullah ibn Umar reported: Allah's Messenger, peace and blessings be upon him, said, "Pay the worker his wages before his sweat dries." (Source: Ibn Majah 2443, Class: Authentic (Saheeh)).

c. Prohibiting Usury Practices. The prohibition of usury is an effort to improve health efficiency and eliminate interest, which will result in lower production costs, thereby increasing efficiency (Ali and Ascarya, 2009: 114)

2. Optimizing Islamic Perspective Output on efficient labor practices related to the following principles:

a. Specialization and Work Division. Specialization will explain the uniqueness and results in the professional skills of the employees [see Alharitsi (2003: 93)]. Having employees who do special work can increase productivity. Therefore, the division of labor increases efficiency, while maximizing the special skills of 
The $1^{\text {st }}$ International Conference on Business and Engineering Management (IConBEM)

February $1^{\text {st }} 2020$, Institut Teknologi Sepuluh Nopember, Surabaya, Indonesia

employees. Conversely, if employees move from one task to another, efficiency may decrease.

b. Avoid waste and waste of production. Al Mawardi, who was appointed in Ali and Ascarya (2009: 114), states that nerves are errors using the right dosage, whereas tabdziris errors use the right allocation. Meanwhile, Israf pays attention to expenses, and is therefore related to consumption.

c. Not Confiscating the Rights of Others By respecting the obligations of maintaining property, Islam also provides guidance on matters relating to contract law or general rules for transactions. Islam prohibits all forms of injustice in economic activities. [Fauzia and Riadi (2014: 436)]

d. Benefits of Production In production activities, Islam considers the distribution of benefits of production among the greatest number of people and in the most equitable manner the most important interests. This also encourages the avoidance of wasteful production output, as stated in Surah Al-Mu'minuun: "And those who turn away from bad speech"

\section{RESULTS AND DISCUSSION}

\section{A. The efficiency of institutions and zakat in Indonesia}

The financial performance of amil zakat institutions in Indonesia based on several research variables as a whole is still said to be safe [11]. One increase in efficiency is caused by an increase in the efficiency of zakat funds in all input variables. Balanced with program, service, office inventory and other operational costs [12]. Efficiency goes on because the actual is t same as a target that was determined by DEA [13]. Some of the previous studies that obtained results that categorize zakat fund management as efficient is shown in Table 3 .

Although many of the previous studies have produced a conclusion that tending to zakat fund management institutions experiences a level of efficiency, it is not absolute, in the sense that the effectiveness of zakat fund management institutions often fluctuates.

There are even some studies that show that the management of zakat funds is still not efficient due to the distribution of zakat funds to ashnaf is still less than optimal [14].

In addition there are also studies conducted to BAZNAS and LAZNAS in 2012-2016, also produced 4 institutions that are already efficient and 15 institutions of zakat are still inefficient [11]. The cause of inefficiency in zakat institutions is mainly because of the high operational costs incurred and the low revenues from zakat funds obtained and the distribution of zakat funds is only used for the short term. It is also caused by the distribution of zakat funds to ashnaf is still less than optimal.

\section{B. The effectiveness of zakat fund institutions and poverty alleviation and income distribution.}

The main results suggest that the incidence, depth and severity of poverty amongst the recipients have decreased due to the contributions from zakah organizations [1].
The study suggests that, in general, the present zakat distribution programmes can alleviate poverty and reduce income inequality among the observed zakat beneficiaries [15].

Hereby suggesting that the observed households are better off in terms of income inequality one year after the zakat distribution programmes [15].

Average from the distribution of funds channeled amil zakat institutions to muzakki $70-60 \%$ can improve the economic welfare of recipients of zakat although some have only experienced $30 \%$ increase [15]-[18].

Factors that could be improvements in maximizing the effectiveness and capacity of Zakat fund management institutions for equitable distribution of national income. it is strongly suggested that zakah organizations should increase effectiveness of the zakah targeting and implement more effective poverty-focused programs particularly within the productive economic programs aimed to reduce poverty and income inequality.

Collaborative and integrated programs in cooperation with other institutions, particularly between the non-profit and the government zakah agencies, are also recommended. The initiatives are expected to increase the impacts of zakah in reducing poverty and accelerate the achievement of a more prosperous Islamic society in the future.

In addition, the support and political will of the government and parliament of the Republic of Indonesia is required, including regulations and the allocation of governmental budget, in order to enhance and optimise the role of zakat and of BAZNAS as the national coordinating institution for zakat management in Indonesia. Cooperation and synergy between BAZNAS, other zakat institutions and the government are also urgently needed to solve the dual problems of poverty and income inequality in the country in a more effective and efficient manner

\section{CONCLUSION}

\section{A. Summary of the Research}

This study shows that zakat be an important role in poverty alleviation and income inequality reduction.Although the management of zakat funds is still not fully efficient and requires some encouragement and innovation in empowerment programs, especially in the productive economic program, gradually the zakat institution continues to experience improvements over the previous years.

Therefore, economic policy must include zakat as one of the government's economic policies so that it can be optimized in the distribution of zakat funds in poverty alleviation and income distribution.

Making zakat as one of the economic policies because based on previous research there is a lack of optimizing the equal distribution of utilization and distribution of zakat funds, one of which is caused by funds [4]. In addition, the collection of zakat funds in Indonesia which is still not mandatory so that it requires individual awareness. To instill the need for socialization of the ZIS movement that can be done as early as possible for school children ranging from 
The $1^{\text {st }}$ International Conference on Business and Engineering Management (IConBEM)

February $1^{\text {st }} 2020$, Institut Teknologi Sepuluh Nopember, Surabaya, Indonesia

elementary school to high school, to foster sympathy, gratitude and social;

In addition, building trust in the society of zakat fund institution is also needed. So that more zakat funds can be collected which will have implications for the wider utilization and benefits that can be felt by the community.

\section{B. Research Limitations and Future Work}

The author acknowledges that although all the conventions of a Systematic Literature Review (SLR) have beenfollowed, this study still has a few possible limitations.First of allthis paper is only a critical review of previous research studies so there is a need for research to strengthen existing conclusions,

Management of Zakat fundsis gaining global attention,to be used as state revenue that can be used as a driver of the country's economy, in this paper the reference research is only limited to the efficiency of the performance of zakat fund management institutions found in Indonesia. Future Research should launch a research that also compels zakat fund management in other well-organized countries so that it can make wider input for the development of zakat fund management in Indonesia.

\section{REFERENCES}

[1] R. A. Kasri, "Effectiveness of zakah targeting in alleviating poverty in Indonesia," Al-Iqtishad J. Islam. Econ., vol. 8, no. 2, pp. 169-186, 2016, doi: 10.15408/aiq.v8i2.3005.

[2] K. A. Meerangani, "The effectiveness of zakat in developing muslims in Malaysia," Insa. J. Islam Humanit., vol. 3, no. 2, pp. 127-138, 2019, doi: 10.15408/insaniyat.v3i2.11315.

[3] M. R. Embong, R. Taha, and M. N. M. Nor, "Role of zakat to eradicate poverty in Malaysia," J. Pengur. (UKM J. Manag., vol. 39, pp. 141-150, 2013.

[4] P. P. Harto, V. S. Anggraeni, and A. Bayinah, "Komparasi kinerja keuangan Lembaga Amil Zakat," J. Akunt. DAN Keuang. Islam, vol. 6, no. 1, pp. 19-33, 2019, doi: 10.35836/jakis.v6i1.7.

[5] J. Hemsley-Brown and I. Oplatka, "Universities in a competitive global marketplace: A systematic review of the literature on higher education marketing," Int. J. Public Sect. Manag., vol. 19, no. 4, pp. 316-338, 2006, doi: 10.1108/09513550610669176.

[6] L. Lusiana and M. Suryani, "Metode SLR untuk mengidentifikasi isu-isu dalam Software Engineering," SATIN (Sains dan Teknol. Informasi), vol. 3, no. 1, pp. 1-11, 2014, doi: 10.33372/stn.v3i1.347.

[7] M. Razavian, B. Paech, and A. Tang, "Empirical research for software architecture decision making: An analysis," J. Syst. Softw., vol. 149, pp. 360-381, 2019, doi: 10.1016/j.jss.2018.12.003.

[8] B. R. Barricelli, F. Cassano, D. Fogli, and A. Piccinno, "End-user development, end-user programming and end-user software engineering: A systematic mapping study," J. Syst. Softw., vol. 149, pp. 101-137, 2019, doi: 10.1016/j.jss.2018.11.041.

[9] K. S. Khan, R. Kunz, J. Kleijnen, and G. Antes, "Five steps to conducting a systematic review," J. R. Soc. Med., vol. 96, no. 3, pp. 118-121, 2003, doi: 10.1177/014107680309600304.

[10] M. Shahril Ahmad Razimi, A. Rahim Romle, and M. Farid Muhamad Erdris, "Zakat management in Malaysia: A review," Am. J. Sci. Res., vol. 11, no. 6, pp. 453-457, 2016, doi: 10.5829/idosi.aejsr.2016.453.457.

[11] S. Suhail, F. Adam, and A. J. W. Mahri, "The efficiency of zakat institutions in Indonesia in 2012-2016," in The 2nd International Conference on Islamic Economics, Business, and Philanthropy (ICIEBP) Theme: "Sustainability and Socio Economic Growth," 2019, vol. 3, no. 13, p. 795, doi: 10.18502/kss.v3i13.4247.

[12] R. R. Djayusman and M. K. Abdillah, "Analisis efisiensi lembaga amil zakat terhadap pengentasan kemiskinan," Islam. Econ. J., vol. 1, no. 2, p. 189, 2015, doi: 10.21111/iej.v1i2.350.

[13] A. Lestari, "Efisiensi kinerja keuangan Badan Amil Zakat Daerah (BAZDA): Pendekatan Data Envelopment Analysis (DEA)," $J$. Ekon. Stud. Pembang., vol. 16, no. 2, pp. 177-187, 2015, doi: 10.18196/jesp.2015.0050.177-187.

[14] A. S. Rusydiana and S. Al Farisi, "The efficiency of zakah institutions using data envelopment analysis," Al-Iqtishad J. Islam. Econ., vol. 8, no. 2, 2016, doi: 10.15408/aiq.v8i2.2876.

[15] Q. Ayuniyyah, A. H. Pramanik, N. M. Saad, and M. I. Ariffin, "Zakat for poverty alleviation and income inequality reduction," $J$. Islam. Monet. Econ. Financ., vol. 4, no. 1, pp. 85-100, 2018, doi: 10.21098/jimf.v4i1.767.

[16] S. Al-Ayubi, A. Ascarya, and B. T. Possumah, "Examining the efficiency of zakat management: Indonesian zakat institutions experiences," Int. J. Zakat, vol. 3, no. 1, pp. 37-55, 2018, doi: 10.37706/IJAZ.V3I1.66.

[17] I. S. Beik and C. Pratama, "Zakat impact on poverty and welfare of mustahik: A CIBEST model approach," AFEBI Islam. Financ. Econ. Rev., vol. 1, no. 01, pp. 1-12, 2017.

[18] A. H. Romdhoni, "Zakat dalam mendorong pertumbuhan ekonom dan pengentasan kemiskinan," J. Ilm. Ekon. Islam, vol. 3, no. 01, p. 51, 2017, doi: 10.29040/jiei.v3i01.98. 